hypertonus, intrapartum fetal anoxia, rapid labour, and deep transverse arrest of the fetal head. We therefore made a limited comparison between the methods of delivery used in this study and for 945 women of similar gestation and in whom there was no clinical suspicion of cephalopelvic disproportion and who were delivered in the same hospital during 1973. In both groups all labours were induced by an identical technique, except that in 1973 once labour became established the oxytocin infusion rate was not reduced to $7 \mathrm{mU} / \mathrm{min}$ but was maintained at a greater though constant rate.

The incidence of normal delivery was similar in both groups. In the present study no ventouse extractions were necessary and no caesarean sections were performed. In 1973 3\% of the patients were delivered by these methods. Fetal distress was never the indication for operative intervention in patients receiving only $7 \mathrm{mU}$ oxytocin/min to maintain labour. In 1973 fetal distress, confirmed by blood $\mathrm{pH}$ estimation, was the chief indication for operative delivery in $32 \%$ of the group.
Whereas variable amounts of oxytocin are required to induce labour to the stage of $5 \mathrm{~cm}$ dilatation of the cervix within a reasonably short time, our results show that no more than 7 $\mathrm{mU} / \mathrm{min}$ is necessary to maintain labour satisfactorily thereafter. Larger doses at this time may be attended by obstetric problems. We therefore recommend the adoption of a maintenance regimen whenever established labour has been induced.

We are grateful to the nursing staff of the labour ward at Mill Road Maternity Hospital for their help, and to our colleagues Mr. R. D. Atlay and Mr. D. Prysor-Jones for access to patients under their care.

\section{References}

${ }^{1}$ Francis, J. G., Turnbull, A. C., and Thomas, F. F., Fournal of Obstetrics and Gynaecology of the British Commonwealth, 1970, 77, 594.

:Beazley, J. M., and Kurjak, A., Lancet, 1972, 2, 348.

\title{
Volunteer and Clinical Studies with Carfecillin: A New Orally Administered Ester of Carbenicillin
}

\author{
P. J. WILKINSON, D. S. REEVES, R. WISE, J. T. ALLEN
}

British Medical fournal, 1975, 2, 250-252

\section{Summary}

Blood and urine levels of carbenicillin were measured in 10 healthy volunteers and four patients with renal failure after single and multiple oral doses of carfecillin. Urinary levels after $1000-\mathrm{mg}$ doses in healthy subjects were considered sufficient for treatment of Pseudomonas aeruginosa urinary infections, but the serum levels were too low for chemotherapy of systemic infections with this organism even in severe renal failure.

Urinary infections were treated in 35 inpatients with a seven-day course of carfecillin. The infection was eradicated in 21 cases $(60 \%)$. In 12 cases the pathogen was Ps. aeruginosa, which was eradicated from eight patients $(67 \%)$. Many patients had severe urinary tract disease. Side effects were virtually absent.

\section{Introduction}

Carfecillin (Uticillin) is the phenyl ester of carbenicillin substituted in the $\alpha$-carboxyl position on the active side chain, which greatly increases the oral absorption of the drug. Esterification is a well-known method of increasing the absorption of antibiotics from the gastrointestinal tract-for example, the esters of erythromycin. Once absorbed, carfecillin is rapidly hydrolysed to carbenicillin and phenol, ${ }^{1}$ the phenol moiety being quickly detoxicated by conjugation as glucuronide and sulphate and excreted in the urine. Excretion of the antibiotic is predominantly renal and high levels of carbenicillin appear in the urine though the relatively short serum half life, even in severe renal

\section{Southmead Hospital, Bristol BS10 5NB}

P. J. WILKINSON, M.B., B.CHIR., Senior Registrar

D. S. REEVES, M.B., M.R.C.PATH., Consultant Medical Microbiologist

R. WISE, M.B., M.R.C.PATH., Senior Registrar (Present address: Department of Medical Microbiology, Dudley Road Hospital, Birmingham)

J. T. ALLEN, B.SC., Senior Biochemist failure ${ }^{2}$ would suggest either a natural loss of antipseudomonal activity in vivo or else an extrarenal pathway of excretion.

This study was designed to investigate the human pharmacology and toxicology of carfecillin and assess the drug's value in treating urinary infections in hospital inpatients, particularly those in whom Pseudomonas aeruginosa was the causative pathogen.

\section{Patients and Methods}

VOLUNTEER STUDY

Carfecillin $500 \mathrm{mg}$ or $1000 \mathrm{mg}$ by mouth (equivalent to $397 \mathrm{mg}$ and $794 \mathrm{mg}$ of carbenicillin free acid respectively) was given to 10 healthy volunteers two hours after a light breakfast of beverage and toast. Carbenicillin levels were assayed in serial blood samples over eight hours during which about $125 \mathrm{ml}$ of water was allowed every half hour. Urinary recovery of carbenicillin was measured over three consecutive four-hour periods from the beginning of the study. All serum and urine carbenicillin concentrations were assayed by a wellplate microbiological diffusion assay method using Ps. aeruginosa (NCTC 10490) as test organism. Serum samples were also investigated for the presence of free phenol by a standard gas-liquid chromatographic method, using an ether/acid extraction process which could detect less than $0.5 \mathrm{mg} / \mathrm{l}$ free phenol.

Four of the volunteers subsequently took either $500 \mathrm{mg}$ or 1000 $\mathrm{mg}$ of carfecillin every eight hours over four days while receiving their normal diet. Serial carbenicillin levels were determined as before on days two and four, and all urine was collected for assay throughout the period.

Four patients with renal failure (creatinine clearance $\leqslant 2.2 \mathrm{ml} / \mathrm{min}$ ) who had given informed consent took either two or three doses of carfecillin $1000 \mathrm{mg}$ by mouth at four-hourly intervals. Serum carbenicillin levels were assayed throughout the period. Two of the patients were anuric, so urinary carbenicillin levels were measured only in two.

\section{THERAPEUTIC TRIAL}

A therapeutic trial of carfecillin in 35 inpatients with urinary infections was then undertaken. Doses of $1000 \mathrm{mg}$ were given by mouth every eight hours for seven days. Serum levels of carbenicillin were measured in 18 patients one and two hours after the initial dose, and the urinary recovery of carbenicillin was determined in all patients 
for the first $\mathbf{4 8}$ hours of the course, when the creatinine clearance was also measured. Urinary infections were diagnosed by a growth of more than $10^{5}$ organisms per $\mathrm{ml}$ of urine in single culture or, with one other species, isolated from two successive mid-stream specimens, or from a single catheter specimen of urine.

Pregnant patients or those with a history of penicillin allergy were not treated. No patient was included if routine laboratory disc sensitivity testing had shown the initial pathogen to be resistant to carbenicillin.

Further urine samples were cultured after 14 and 42 days. Eradication of the initial pathogen at both these times was considered to be the criterion of bacteriological cure. The minimum inhibitory concentration (M.I.C.) of carbenicillin for each of the isolates was determined by a standard agar dilution method.

Full haematological indices, plasma urea, serum transaminases, and liver function were determined for all volunteers and patients at the beginning and end of each study or course of treatment.

\section{Results}

\section{PHARMACOLOGY}

\section{Serum Levels}

Serum levels of carbenicillin in the healthy volunteers varied considerably, but peak levels were less than $10 \mathrm{mg} / \mathrm{l}$ in all cases (see fig.). After four to six hours the drug was undetectable in many cases. Levels of up to $9.8 \mathrm{mg} / 1$ were found two hours after taking $1000 \mathrm{mg}$ of carfecillin on days two and four in healthy volunteers taking the four-day course.

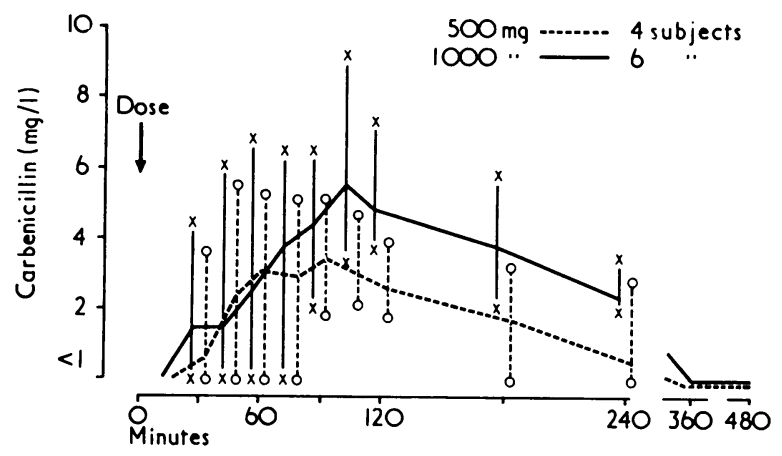

Mean serum levels of carbenicillin (and ranges) after single oral doses of carfecillin in 10 healthy volunteers.

In the four patients with severe renal failure the dosage regimen was designed to ascertain whether poor renal function would enable serum levels adequate for systemic antipseudomonal activity to be achieved. A shorter dose interval (4 hours) was therefore adopted, and considerably higher concentrations were obtained, which seemed to reach a plateau after the third four-hourly dose of $1000 \mathrm{mg}$. With the small numbers no statistically significant difference was found between the mean two-hour carbenicillin concentrations after a single dose of $1000 \mathrm{mg}$ of carfecillin in the four healthy volunteers (mean $5.1 \mathrm{mg} / \mathrm{l}$ ) and in the four renal failure patients (mean $8.8 \mathrm{mg} / \mathrm{l}$ ).

Serum levels in 18 patients in the therapeutic trial one and two hours after the initial dose of $1000 \mathrm{mg}$ showed great variations (at one hour, mean $6.7 \mathrm{mg} / 1$, range $0-18.5 \mathrm{mg} / 1$; at two hours, mean 7.6 $\mathrm{mg} / \mathrm{l}$, range $1.8-15.0 \mathrm{mg} / \mathrm{l})$. This was to be expected from the variation in the patients' renal function (creatinine clearance 14-119 $\mathrm{ml} / \mathrm{min}$ ), and the difficulty of standardizing the timing of the dose with respect to mealtimes.

\section{Urinary Levels}

The urinary carbenicillin levels in healthy volunteers varied greatly after a single dose of carfecillin. Maximum excretion was in the first four hours when mean levels were $112 \mathrm{mg} / \mathrm{l}$ after $500 \mathrm{mg}$ (range $54-180 \mathrm{mg} / \mathrm{l}$ ) and $434 \mathrm{mg} / \mathrm{l}$ after $1000 \mathrm{mg}$ (range 52-1120 $\mathrm{mg} / \mathrm{l})$. One of the two non-anuric patients with renal failure had a level of $49 \mathrm{mg} / \mathrm{l}$ in a 12-hour collection of urine, and no antibiotic was detected in the urine of the other. About $25 \%$ of the carbenicillin equivalent of the administered dose was excreted in the urine on each dosage regimen, which is in agreement with the results of Jones. ${ }^{3}$

In 19 patients from the therapeutic trial with good renal function (creatinine clearance $>40 \mathrm{ml} / \mathrm{min}$ ) the mean urinary carbenicillin levels $( \pm S$.D.) during the first 24-hour period of treatment with $1000 \mathrm{mg}$ of carfecillin every eight hours was $286+171 \mathrm{mg} / 1$ (range $99-756 \mathrm{mg} / \mathrm{l})$. The mean recovery over this period was $21.85 \pm$ $6.36 \%$ of the administered dose. In the second 24 -hour period the mean level was $295 \pm 124 \mathrm{mg} / \mathrm{l}$ (range $131.8-493.7 \mathrm{mg} / \mathrm{l}$ ) and the mean cumulative excretion over the first 48 hours $24 \cdot 2 \pm 7.35 \%$. In eight patients with moderate impairment of renal function (creatinine clearance $10-40 \mathrm{ml} / \mathrm{min}$ ) mean excretion over the same periods was $11.96 \pm 7.09 \%$ and $16.69 \pm 7.13 \%$ respectively. The mean levels obtained were $391 \pm 307 \mathrm{mg} / 1$ (range $44-880 \mathrm{mg} / \mathrm{l}$ ) in the first 24 hours and $393 \pm 129 \mathrm{mg} / 1$ (range 211-597 mg/l) over the next 24 hours. The difference in recovery between the two groups was statistically significant only at $\mathbf{P}<0.10$ (Willcoxon two-sample test). Mean urinary concentrations in all cases were greater than $100 \mathrm{mg} / \mathrm{l}$ over this period.

\section{THERAPEUTIC TRIAL}

The infecting organisms in the 35 patients treated over seven days were Ps. aeruginosa (12 cases), Escherichia coli (9), Proteus mirabilis (4), Pr. vulgaris (1), Pr. rettgeri (1), Providencia stuartii(1), Citrobacter freundii (1), Streptococcus faecalis (2), Staphyloccus aureus (2), and Staph. albus (2). The overall bacteriological cure rate, as defined by eradication of the infecting organisms at 14 and 42 days after beginning treatment with or without reinfection by a different organism during that period, was $60 \%$ (21 cases). The cure rate for Ps. aeruginosa infections was $67 \%$ (eight out of 12 cases). Failures of treatment are shown in the table.

\section{SIDE EFFECTS AND TOLERABILITY}

Two volunteers taking $500 \mathrm{mg}$ of carfecillin for four days showed a rise in eosinophil count from 0 to $9 \%$ and 0 to $6 \%$, which incidentally, coincided with a rise in pollen count from "low" to "very high." Eosinophilia was not noted in any patient in the therapeutic trial. One healthy volunteer had mild diarrhoea and two patients also complained of mild diarrhoea, but no rashes, nausea, or other side effects were observed. The unpleasant after taste associated with the indanyl ester was not noted. In no case did treatment have to be stopped. There were no changes in any other haematological or biochemical values which were attributable to carfecillin. No free phenol was detected in any of the samples of blood from the volunteers.

Details of 14 Patients in whom Treatment Failed

\begin{tabular}{|c|c|c|c|c|c|}
\hline $\begin{array}{l}\text { Infecting } \\
\text { Organism }\end{array}$ & $\begin{array}{l}\text { No. of Patients } \\
\text { Treated }\end{array}$ & $\begin{array}{l}\text { No. in whom } \\
\text { Treatment Failed }\end{array}$ & $\begin{array}{l}\text { Case } \\
\text { No. }\end{array}$ & $\begin{array}{l}\text { M.I.C. of Carbenicillin } \\
\text { for organism } \mathrm{mg} / \mathbf{1}\end{array}$ & Possible Contributory Causes of Failure and Other Conditions \\
\hline Ps. aeruginosa & 12 & 4 & $\begin{array}{l}1 \\
2 \\
3 \\
4 \\
5 \\
6 \\
7\end{array}$ & $\begin{array}{c}16 \cdot 0 \\
16 \cdot 0 \\
64 \cdot 0 \\
128 \cdot 0 \\
10 \cdot 0 \\
0 \cdot 25\end{array}$ & $\begin{array}{l}\text { Carcinoma of bladder } \\
\text { Benign prostatic hypertrophy } \\
\text { Chronic functional bladder hypotonia with persistent residual urine } \\
\text { Urethral stricture, periurethral abscess } \\
\text { Carcinoma of colon (operated on on last day of carfecillin course) } \\
\text { Megaloblastic anaemia (82-year-old woman) }\end{array}$ \\
\hline E. Coli & 9 & 6\{ & $\begin{array}{l}7 \\
8 \\
9\end{array}$ & $\begin{array}{r}1 \cdot 0 \\
8 \cdot 0 \\
4 \cdot 0\end{array}$ & Prostatic hypertrophy \\
\hline Pr. mirabilis & 4 & 3\{ & $\begin{array}{l}10 \\
11 \\
12 \\
13\end{array}$ & $\begin{array}{c}1 \cdot 0 \\
0 \cdot 25 \\
16 \cdot 0 \\
0 \cdot 125\end{array}$ & $\begin{array}{l}\text { Ischaemic heart disease (75-year-old woman) } \\
\text { Prostatic hypertrophy } \\
\text { Prostatic hypertrophy }\end{array}$ \\
\hline $\begin{array}{l}\text { Staph. aureus } \\
\text { Others }\end{array}$ & $\begin{array}{l}2 \\
8\end{array}$ & $\begin{array}{l}1 \\
0\end{array}$ & 14 & $8 \cdot 0$ & Prostatic hypertrophy \\
\hline
\end{tabular}




\section{Discussion}

Carbenicillin is an established antibiotic for infections due to two difficult groups of organisms-Ps. aeruginosa and the indolepositive Proteus spp. ${ }^{4}$ Non- $\beta$-lactamase-producing $E$. coli are very susceptible to carbenicillin and Str. faecalis moderately so. Though carbenicillin is particularly useful against Ps. aeruginosa high parenteral doses (up to $30 \mathrm{~g} /$ day) may be needed to treat systemic infections with this organism. High urinary concentrations of carbenicillin have been reported, ${ }^{5}$ with intramuscular doses of $500 \mathrm{mg}$ giving concentrations greater than $500 \mathrm{mg} / \mathrm{l}$. Such levels will eradicate sensitive $P$ s. aeruginosa (M.I.C. $\leqslant 100$ $\mathrm{mg} / \mathrm{l}$ ) but the injections are often painful and the patient usually needs to be in hospital.

Serum levels in volunteers and patients after oral carfecillin were found to be insufficient to treat systemic infection with Ps. aeruginosa, even when renal function was impaired, but urinary levels were sufficient to suggest that urinary infections might be eradicated.

In severe renal failure the mean serum half life of carbenicillin is only $10-20$ hours, $^{2}$ which is short compared with that of gentamicin (40-60 hours $\left.{ }^{6}\right)$ in similar patients. This suggests that there is a relatively rapid rate of decay of antipseudomonal activity in vivo or an extrarenal pathway of elimination or both. Berrill et al, ${ }^{7}$ using the indanyl ester of carbenicillin, thought that gastrointestinal absorption of the drug might be impaired in renal failure and adduced lower serum levels as evidence. They could not exclude increased extrarenal excretion, and our patients and volunteers with renal impairment tended to have higher serum levels than those with normal renal function.

The incidence of undesirable side effects with carfecillin compares favourably with that of indanyl ester of carbenicillin, which is also orally absorbed. Berrill et al. ${ }^{7}$ treated eight patients with the latter drug and stopped treatment in two because of rashes. Two others had diarrhoea. Wallace et al. ${ }^{8}$ reported 38 side effects in 26 patients, and treatment in three patients had to be stopped. In a double-blind series $^{\circ}$ eight patients out of 20 receiving carbenicillin indanyl sodium suffered side effects and the drug was withdrawn from one of these who had severe vomiting. Lees and Harding ${ }^{10}$ noted that $10.5 \%$ of patients who were given carfecillin capsules had diarrhoea, but only $4.35 \%$ who received the tablet form (as now marketed) complained of this side effect.

Our results compare favourably with those of Berrill et al, ? particularly as our dose was lower and given for seven days instead of 14. Our patients also had a high prevalence of urinary tract abnormalities. The overall cure rate with indanyl carbenicillin in the series of Ries et al. ${ }^{9}$ was $50 \%$ as compared with $60 \%$ in our series, though no pseudomonas infections were treated with indanyl carbenicillin in the former series as compared with 12 in ours.

Ps. aeruginosa rarely causes primary, uncomplicated urinary tract infection but it may cause infection secondary to other urinary tract conditions or operations where catheterization may have been necessary. ${ }^{11}$ The only antibiotic therapy available to such patients is by the parenteral route, which usually means a stay in hospital. The availability of a well-tolerated oral agent for such cases represents a therapeutic advance. Further studies with carfecillin are necessary, and possibly a longer course of treatment should be given in difficult cases, but this drug promises to be a useful oral treatment of urinary infections when the choice of effective antibiotics is limited.

The formulation of carfecillin to be marketed in the United Kingdom will differ slightly from that used in our studies reported here, the main change being improved oral absorption. ${ }^{3}$ Its performance in curing infection will probably be at least as good as that of the previous formulation, but side effects and tolerability will need to be reassessed.

We thank Mr. M. J. Bywater, Mr. H. A. Holt, and Mrs. H. D. Bennett for technical help; Dr. E. A. P. Croydon of Beecham Pharmaceuticals for providing the carfecillin and for helpful advice; and our clinical colleagues whose patients we treated.

\section{References}

1 Rolinson, G. N., personal communication, 1973.

${ }^{2}$ Eastwood, J. B., and Curtis, J. R., British Medical fournal, 1968, 1, 486.

3 Jones, K. H., personal communication, 1974

4 Brumfitt, W., Percival, A., and Leigh, D. A., Lancet, 1967, 1, 1289.

Meyers, B. R., Sabbaj, J., and Weinstein, L., Archives of Internal Medicine, $1970,125,282$.

${ }^{6}$ Gingell, J. C., and Waterworth, P. M., British Medical fournal, 1968, 2 , 19.

${ }^{2}$ Berrill, W. T., et al., British fournal of Urology, 1973, 45, 563.

${ }^{8}$ Wallace, J. F., et al., Antimicrobial Agents and Chemotherapy: Proceedings of the 10th Conference, 1970, p. 223. Bethesda, American Society for Microbiology, 1971.

9 Ries, K. M., et al., Antimicrobial Agents and Chemotherapy, 1973, 4, 593. ${ }^{10}$ Lees, L. J., and Harding, J. M., British Fournal of Clinical Practice, 1974,

11 Gould, J. C., in Urinary Tract Infection, ed. F. O'Grady and W. Brumfitt, p. 43. London, Oxford University Press, 1968.

\title{
Recovery from Goodpasture's Syndrome after Immunosuppressive Treatment and Plasmapheresis
}

\author{
C. M. LOCKWOOD, J. M. BOULTON-JONES, R. M. LOWENTHAL， I. J. SIMPSON, \\ D. K. PETERS, C. B. WILSON
}

British Medical fournal, 1975, 2, 252-254

\section{Summary}

A patient with Goodpasture's syndrome has recovered after treatment with immunosuppressive drugs (cyclo-

Renal Unit, Hammersmith Hospital, Royal Postgraduate Medical School, London W12 0HS

C. M. LOCKWOOD, M.R.C.P., Registrar

J. M. BOULTON-JONES, M.R.C.P., Senior Registrar

R. M. LOWENTHAL, M.B. M.R.C.P., Research Fellow

I. J. SIMPSON, M.R.A.C.P., Research Fellow

D. K. PETERS, M.R.C.P., Reader in Medicine

Department of Immunopathology, Scripps Clinic and Research Foundation, La Jolla, California

C. B. WILSON, M.D., Associate Member of Department phosphamide and prednisolone) and removal of circulating antibodies by plasma exchange. This was performed on seven occasions and seems to have hastened the decline in circulating antibody levels. Undertaken early in the course of the disease plasmapheresis could prove a useful addition to its therapy.

\section{Introduction}

Renal injury in most patients with Goodpasture's syndrome is known to be mediated by antibodies directed at the glomerular basement membrance (G.B.M.). ${ }^{1-3}$ This syndrome-the association of lung haemorrhage and glomerulonephritis-is characterized by a rapidly fatal course terminating in renal failure or asphyxia from uncontrolled lung haemorrhage. Since 